\title{
Empowerment of Youth Community Tourism Management in Sukamakmur District, Bogor Regency
}

\author{
Muhammad Zid, Asma Irma, Ode Sofyan Hardi, Sony Nugratama Hijrawadia) \\ Departement Education of Geography, University State of Jakarta \\ a)Corresponding Author: sonynugratama@unj.ac.id
}

\begin{abstract}
The varied natural potential makes Bogor Regency has a lot of natural tourism potential. Its location in the highlands adds to the attraction of tourists to visit. One of the natural tourist destinations in Bogor Regency is Cipamingkis waterfall, the location of this waterfall is in Wargajaya Village, Sukamakmur District, Bogor Regency. Sukamakmur district actually has several tourist attractions, such as the Kahyangan villa and the Ciherang waterfall. However, the existence of this tourist attraction has not had a significant impact on the villagers, most of the villagers still rely on agricultural fields as their livelihood. In addition, the village youth have not played a role in the management of tourism objects. They prefer to work outside the village rather than develop their village. Therefore, this community service activity aims to provide training in managing and developing tourism objects in Sukamakmur district, the concept of community-based tourism management or better known as Community Based Tourism (CBT). The training was carried out in three stages, including program socialization, group discussions, and the last stage was tourism management planning. The results of these activities, in the socialization stage, the youth of Sukamakmur district actually have the motivation to manage and develop tourism objects in Sukamakmur district. However, it is constrained by limited knowledge about the management of tourism objects. The second stage of activity tries to dig up information on the existence of the tourist attraction, so that several alternative tourism development plans are obtained. In the last stage, it is activated to try alternative tourism objects that can be developed in Sukamakmur district with the hope that Sukamakmur district becomes a Tourism Village and residents get a positive impact.
\end{abstract}

Key words: Community Tourism, Karang Taruna, Sukamakmur District

\section{INTRODUCTION}

Tourism has a very large role in the development of Indonesia, especially as a foreign exchange earner in addition to oil and gas. This is because Indonesia has great natural resource potential, this potential can be developed into a tourist attraction. The government makes tourism as one of the current developments. Tourism development also aims to introduce and utilize the natural beauty and culture of Indonesia. This means that tourism development in Indonesia cannot be separated from the potential that Indonesia has. Indonesia has a very interesting cultural diversity. This cultural diversity is motivated by the existence of religion, unique customs, and arts that are owned by every tribe in Indonesia. In addition, the beautiful nature will provide a special attraction for tourists, be it mountainous (rural), underwater, and beach nature.

The emergence of the phenomenon of community-based tourism management is a criticism of tourism management that is carried out without involving the community and is seen as less able to empower the community. Community-based tourism (CBT) is a tourism management concept by prioritizing the active participation of the community with the aim of providing welfare for them while maintaining environmental quality, as well as protecting their social and cultural life ( $\mathrm{N}$ et al., 2015). The concept of community-based tourism is compatible with sustainable tourism (sustainable tourism) which requires community participation so as to improve the quality of life of the people living in the area (Álvarez-García et al., 2018). Based on the results of research conducted (Dodds et al., 2018) that if tourism management with the CBT model is developed properly it can be a mechanism for alleviating poverty and also a means to 
improve the quality of life, providing greater economic benefits for the community. The motivation of the community to participate together in managing their territory is different, this becomes a challenge when there is no common vision in developing their territory through the existing potential. Community participation in this case through the CBT model is influenced by social, cultural, economic and sometimes local political tensions in each environment (Mayaka et al., 2018). This should be overcome by the role of the village government in anticipating the existing challenges.

Development of Tourism Potential The development of the tourist village itself in fact has benefits in the economic, social, educational, science and technology, socio-cultural, and environmental fields (Andayani et al., 2017). This is in accordance with the demand that the village must be able to play an active and independent role in meeting its own needs, all the potential that exists in the village needs to be maximized so that it is able to prosper the community (Saputra et al., 2018). In the economic field, tourist villages can improve the economy of local communities and at the regional level. Tourism villages spur the potential for the growth of the creative economy, where residents make souvenirs and various handicrafts that have a high selling value (Hadi Sumarto \& Dwiantara, 2020). In addition, there are many food stalls, basic food stalls, and so on in tourist villages. The existence of a tourist village can prosper the people living in the village. A strong commitment in developing tourist villages needs to be established between the village government, community leaders and village organizations so that the desired goals are realized (Gautama et al., 2020). In addition, in the social field, tourist villages can create employment opportunities for local residents, especially village youth. Not a few young people who become tour guides and eventually earn a steady income. Youth can play a role in change in the village. The existence of the youth organization Karang Taruna can contribute to making changes. As done by the Youth Organization organization in the Rakit District, Banjarnegara Regency which carries out organizational activities in the development of productive economic enterprises (Sarno, 2019). Youth empowerment through the Karang Taruna organization should be increased through activities that have a major influence on village development, in addition to managing tourist villages, the role of youth organizations can also increase environmental awareness (Widyastuty, 2019). The existence of tourist objects in Sukamakmur District is still not managed professionally, this can be seen from the withdrawal of entrance tickets, access roads, facilities and infrastructure that exist in these attractions. Everything is still managed unplanned, besides the role of the village in this case the Village-Owned Enterprises (BUMDes) is still not much involved in the management of tourism objects in Sukamakmur District. The existence of youth organizations such as Karang Taruna should be a driving force in the management and development of resources in Sukamakmur District which has the potential to be developed professionally. In addition, it can also empower the local community's economy with various types of businesses according to the potential of the village.

This activity offers several solutions by involving the community, especially youth who are members of the Karang Taruna organization to develop tourism potential in Sukamakmur District. The solution offered in this activity is to conduct a participatory mapping of the potential of tourism objects in Sukamakmur District. It is hoped that the distribution map can be an encouragement for the youth and community of Wargajaya Village to develop the potential that exists in their village so that they can increase economic income for the village. In addition to participatory mapping, another solution is to conduct community-based tourism object management training. So that tourism objects can be managed professionally, and involve all the people in Sukamakmur District.

\section{METHOD}

The method used in this Community Service Integrated Real Work Lecture is the method used in this activity in the form of training and increasing understanding of the management of tourism objects in Sukamakmur District. The selection of methods through training is considered 
capable of providing understanding to the community. The community can immediately feel the experience provided by the instructor (Susanti et al., 2020). In addition, the training method was used in mapping the situation of the distribution of tourist objects in Sukamakmur District. Youth organizations in Wargajaya Village are trained to use simple tools to identify tourism objects that have the potential to be developed. While the improvement/understanding method is used to provide additional insight related to the management of tourism objects. The participants were trained in assisting tourists and developing existing tourist objects.

The participants of this activity were the Karang Taruna Sukamakmur district organization, which consisted of 24 people. In addition to members of the Youth Organization, the activity was also attended by village officials such as the Village Supervisory Board and community leaders. This training activity was carried out at the Sukamakmur district Office in September 2020.

\section{RESULTS}

The results achieved in this community service activity program include:

1. Mapping of tourism potential in Sukamakmur District, by plotting existing tourist objects is presented in (Figure 1).

2. Tourism management training for youth organization Karang Taruna in Sukamakmur District (Figure 2).

3. The results of the evaluation of activities distributed through questionnaires to training participants are in the form of graphics (Figure 3).

\section{DISCUSSION}

The results of this activity show that the tourism potential in Sukamakmur district is actually quite a lot, but only a few have been developed to become tourist attractions. The location of the village which is in the hills, actually has natural potential as well as limited accessibility. The activity of mapping the potential of the village is carried out using the Global Positioning Satellite (GPS) which is installed on the participant's mobile phone, while the standard parameters used to assess the feasibility of tourist sites include; road accessibility, potential to see and sell. This $\mathrm{KKN}$ activity is an implementation of the lectures that have been carried out by students in the classroom.

Students of the Geography Education study program are given skills in making situation maps, from this activity a map of the tourism potential found in Village is produced. The existence of a tourism potential map will provide information to the village government and residents in planning development in their village. In addition to producing a map of the potential distribution of tourism, this potential map can be displayed on the Sukamakmur district website page so that it can be seen by the wider community. It is hoped that the map can attract tourists to visit villages in Sukamakmur district.

The driving factor in implementing the program is the enthusiasm of the activity participants. All participants, especially Karang Taruna and village officials, support the running of this program. So that Community Service activities that are integrated with Student Real Work Lectures run without any obstacles. In addition, it is also supported by the strong desire of the participants to work together to build their village. Meanwhile, the inhibiting factors for this activity include the relatively poor accessibility. The roads to Sukamakmur Villages are not all good, some roads are in a damaged condition and have potholes. In addition, the road can only be crossed by two cars so that the vehicle speed cannot use the maximum speed. The absence of public transportation to the location is also an obstacle so that sometimes activities can experience delays. The aspect of human resources is also one of the obstacles, there are still some participants who cannot read and write so that when carrying out group discussions it is necessary to do it carefully. This activity also tries to identify participants' understanding in managing tourism together (figure 2). Based on the information obtained, that in fact the community already knows the management of community-based tourism. However, this has not been implemented in the management of tourism in Sukamakmur district. So that a model can be obtained in the management of tourist objects that are managed in Villages, Sub-District 
The results of the participants' answers from 24 respondents as much as 35 percent do not know about community-based tourism management, and 30 percent have heard but not yet clearly. After this activity, questionnaires were distributed to the participants. The evaluation consists of the usefulness of the material content for participants, the delivery/exposure of the material, as well as sufficient time for discussion and question and answer. There are ten statement items made with answer categories 1 to 4, if the participant fills in the number 1 (one) it means that the participant does not agree; number 2 (two) quite agree; number 3 (three) agree and number 4 (four) strongly agree. Participants who attended this activity actually amounted to almost 35 people, but because not all participants filled out the questionnaire so that the questionnaires were declared valid as many as 32 sheets. There are still participants who have limitations in reading and writing, this can be a concern for further service activities. The following are the results of the assessments given by participants through a questionnaire.

The first part of the evaluation form contains the contents of the material as many as four points are asked, it appears that the number of participants who stated that the content of the material was well organized and easy to understand was 20 participants while 12 participants agreed. At the point of the second statement, there were 13 participants who agreed that the material was very relevant and in line with what was expected, and 18 people who stated strongly agreed. This training is intended for youth in Wargajaya Village, with the hope that they will really recognize the tourism potential there so that it can be utilized as well as possible. In addition, they are also expected to maintain the quality of the existing environment. The third point of the evaluation statement is that the material is sufficient for the preparation of tourism activities in the village, 21 participants who answered strongly agree and 10 people answered that they agreed that the material was sufficient. The fourth point that was asked regarding the content of the material was the ease of the material in providing understanding to residents in developing tourism. The result is as many as 20 participants answered

\section{CONCLUSIONS AND RECOMMENDATIONS}

This community service activity that has been carried out has received a good response from the villages government. Based on the results of distributing questionnaires to participants, it can be seen that there is still a lack of understanding of youth related to community-based tourism. So that assistance is needed for youth in managing tourism in their village, as well as mapping the tourism potential villages in Sukamakmur District. Based on the results of the activities that have been carried out, the villages in Sukamakmur district has tourism potential that can be developed better. However, the active role of the government in involving youth in the tourism development process in Village is still minimal, so it is necessary to strengthen the capacity of the village government in managing tourism by involving youth.

\section{ACKNOWLEDGMENTS}

This community service can be carried out well with the support of (1) Rector Universitas Negeri Jakarta (2) Head of LPPM Universitas Negeri Jakarta (3) Dean of Faculty Social Science (4) Head of Sukamakmur District and all participant involved training program.

\section{REFERENCES}

Álvarez-García, J., Durán-Sánchez, A., Río-Rama, D., \& ... (2018). Scientific coverage in community-based tourism: Sustainable tourism and strategy for social development. Sustainability. https://www.mdpi.com/281566

Andayani, A. A. I., Martono, E., \& Muhamad, M. (2017). Pemberdayaan Masyarakat Melalui Pengembangan Desa Wisata Dan Implikasinya Terhadap Ketahanan Sosial Budaya Wilayah (Studi Di Desa Wisata Penglipuran Bali). Jurnal Ketahanan Nasional, 23(1), 1. https://doi.org/10.22146/jkn.18006

Dodds, R., Ali, A., \& Galaski, K. (2018). Mobilizing knowledge: Determining key elements for success and pitfalls in developing community-based tourism. Current Issues in Tourism. 
https://doi.org/10.1080/13683500.2016.1150257

Gautama, B. P., Yuliawati, A. K., \& ... (2020). Pengembangan desa wisata melalui pendekatan pemberdayaan masyarakat.

BERNAS:

Jurnal

http://www.ejournal.unma.ac.id/index.php/bernas/article/view/414

Hadi Sumarto, R., \& Dwiantara, L. (2020). Pemberdayaan Masyarakat Dalam Tata Kelola Pariwisata Di Kampung Wisata Dewo Bronto Yogyakarta. Journal Publicuho, 2(4), 111. https://doi.org/10.35817/jpu.v2i4.10273

Mayaka, M., Croy, W. G., \& Cox, J. W. (2018). Participation as motif in community-based tourism: a practice perspective. Journal of Sustainable Tourism. https://doi.org/10.1080/09669582.2017.1359278

N, F. A., Krisnani, H., \& Darwis, R. S. (2015). Pengembangan Desa Wisata Melalui Konsep Community Based Tourism. Prosiding Penelitian Dan Pengabdian Kepada Masyarakat, 2(3). https://doi.org/10.24198/jppm.v2i3.13581

Saputra, H., Rudianto, R., Setiawan, D., \& ... (2018). Desa Wisata Hidroponik Sebagai Upaya Pemberdayaan Masyarakat Desa Sidomulyo Kecamatan Anggana Kabupaten Kutai Kartanegara. Jurnal Pengabdian https://jurnal.unimed.ac.id/2012/index.php/jpkm/article/view/9656

Sarno, S. (2019). Pemberdayaan Karang Taruna Kecamatan Rakit Melalui Kegiatan Pengembangan Usaha Ekonomi Produktif Berbasis Masyarakat. Adimas: Jurnal Pengabdian Kepada Masyarakat, 3(2), 1. https://doi.org/10.24269/adi.v3i2.1207

Susanti, S., Apriasih, H., \& Danefi, T. (2020). Pemberdayaan Masyarakat Melalui Pelatihan Kader Posyandu Remaja Uswatun Hasanah Desa Cikunir. ABDIMAS: Jurnal Pengabdian .... http://umtas.ac.id/journal/index.php/ABDIMAS/article/view/579

Widyastuty, S. A. (2019). Pemberdayaan pemuda karang taruna melalui program remaja peduli lingkungan Desa Wisata kebontunggul. Jurnal Penamas Adi Buana. http://jurnal.unipasby.ac.id/index.php/penamas/article/view/1956

\section{APPENDIX}
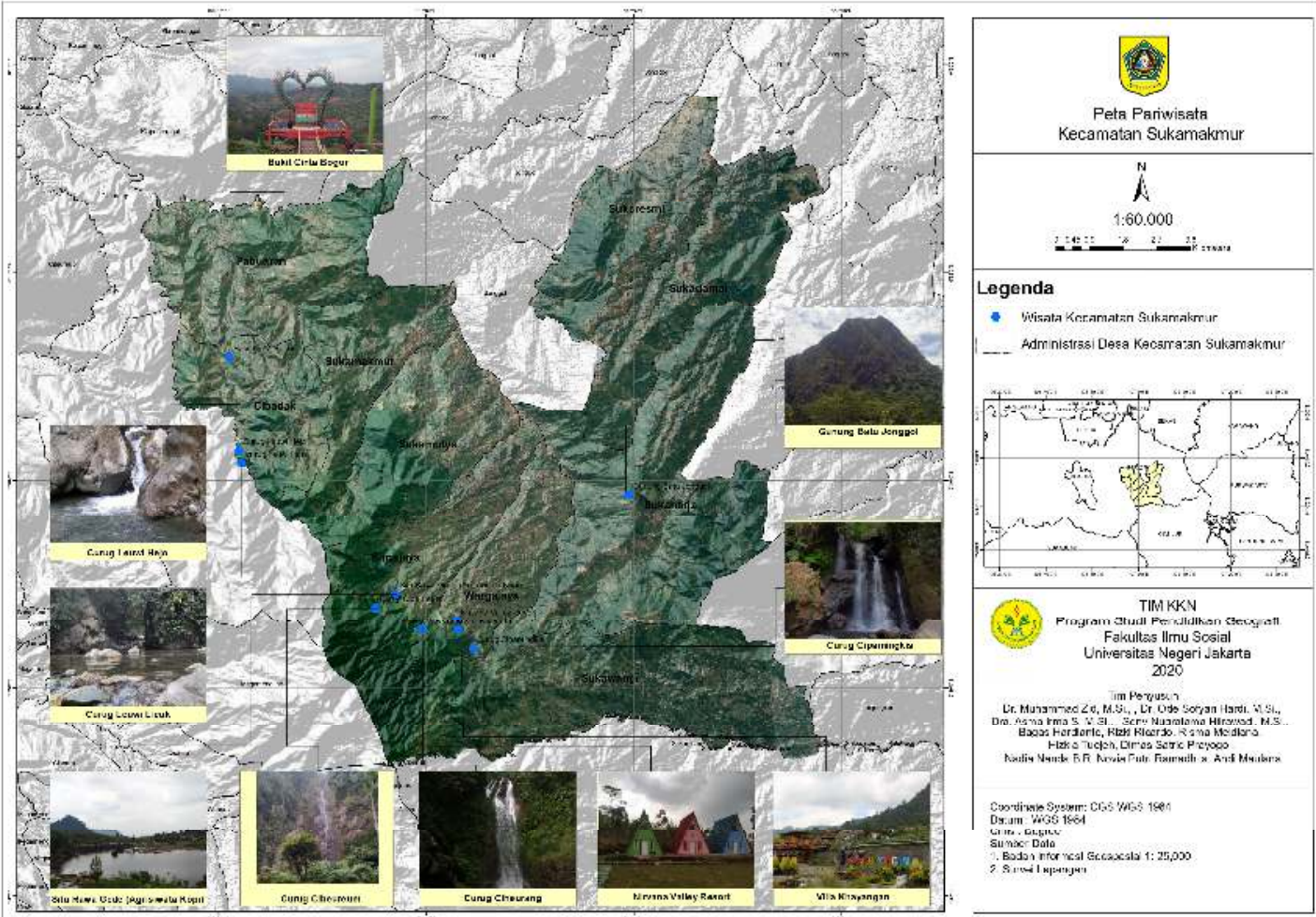

Figure 1. Potential Map Tourism in Sukamakmur District 

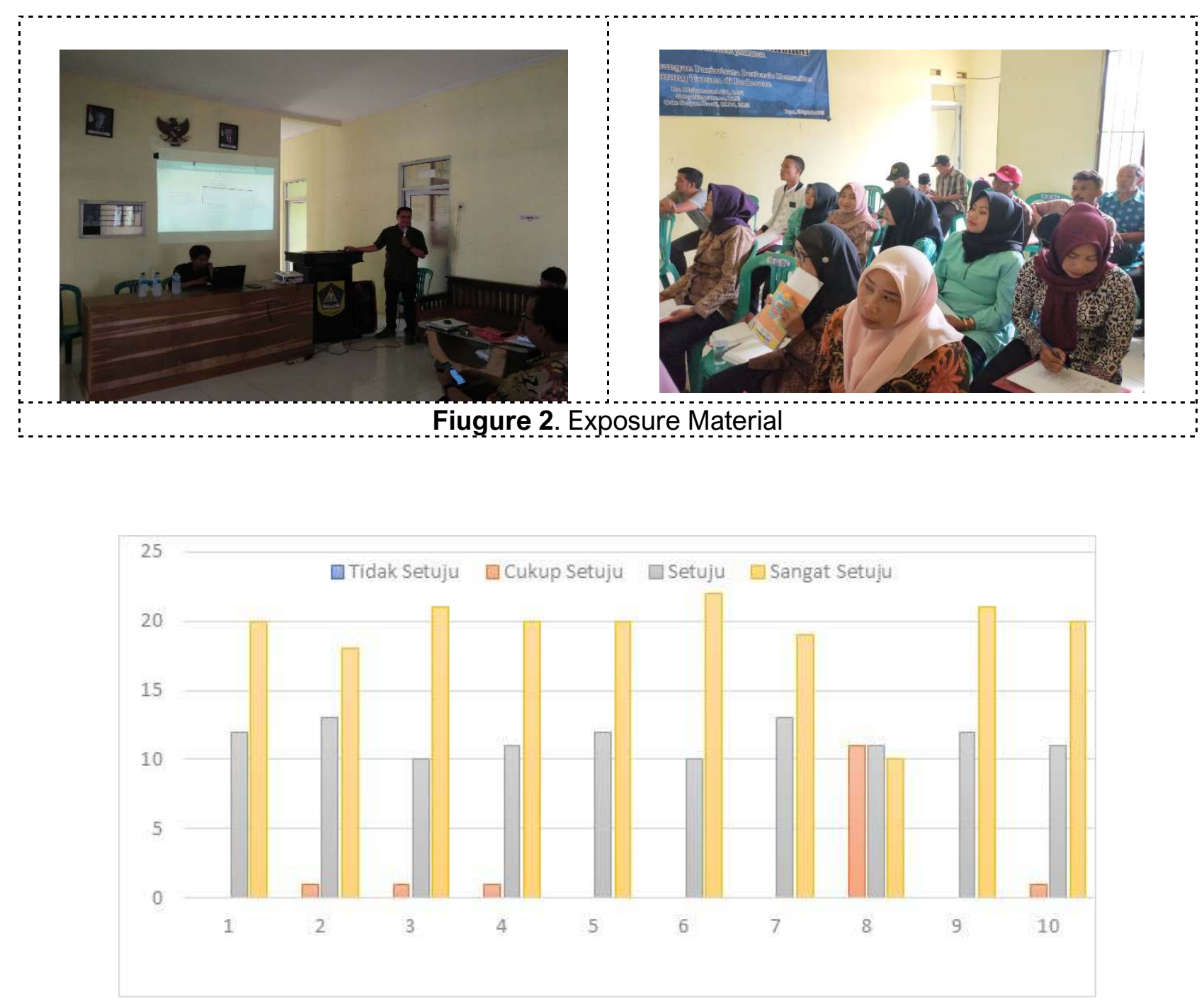

Figure 3. Evaluation Activities 